Article

\title{
Toward the Synthesis and Improved Biopotential of an $N$-methylated Analog of a Proline-Rich Cyclic Tetrapeptide from Marine Bacteria
}

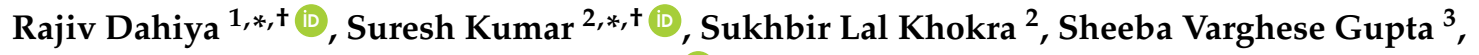 \\ Vijaykumar B. Sutariya ${ }^{3}$, Deepak Bhatia ${ }^{4}\left(\mathbb{D}\right.$, Ajay Sharma ${ }^{5}$, Shamjeet Singh ${ }^{1}$ and \\ Sandeep Maharaj ${ }^{1}$ \\ 1 Laboratory of Peptide Research and Development, School of Pharmacy, Faculty of Medical Sciences, \\ The University of the West Indies, Saint Augustine, Trinidad and Tobago; Shamjeet.Singh@sta.uwi.edu (S.S.); \\ Sandeep.Maharaj@sta.uwi.edu (S.M.) \\ 2 Institute of Pharmaceutical Sciences, Kurukshetra University, Kurukshetra 136119, Haryana, India; \\ slkhokra@kuk.ac.in \\ 3 Department of Pharmaceutical Sciences, USF College of Pharmacy, University of South Florida, \\ Tampa, FL 33612-4749, USA; svarghes@health.usf.edu (S.V.G.); vsutariy@health.usf.edu (V.B.S.) \\ 4 Department of Pharmacogenomics, ICPH Fairfax Bernard J. Dunn School of Pharmacy, \\ Shenandoah University, Fairfax, VA 22031, USA; dbhatia@su.edu \\ 5 Department of Pharmacognosy, Amity Institute of Pharmacy, Amity University, \\ Gwalior 474020, Madhya Pradesh, India; asharma5@gwa.amity.edu \\ * Correspondence: Rajiv.Dahiya@sta.uwi.edu or drrajivdahiya@gmail.com (R.D.); \\ sureshmpharma@rediffmail.com (S.K.); Tel.: +1-868-493-5655 (R.D.) \\ + These two authors contributed equally to this work.
}

Received: 21 June 2018; Accepted: 27 August 2018; Published: 30 August 2018

\begin{abstract}
An $N$-methylated analog of a marine bacteria-derived natural proline-rich tetracyclopeptide was synthesized by coupling the deprotected dipeptide fragments Boc-L-prolyl-L- $N$-methylleucine-OH and L-prolyl-L- $N$-methylphenylalanine-OMe. A coupling reaction was accomplished utilizing $N, N^{\prime}$-Dicyclohexylcarbodidimde (DCC) and 1-Ethyl-3-(3-dimethylaminopropyl) carbodiimide $(\mathrm{EDC} \cdot \mathrm{HCl})$ as coupling agents and Triethylamine (TEA) or $\mathrm{N}$-methylmorpholine (NMM) as the base in the presence of the racemization suppressing agent. This was followed by the cyclization of the linear tetrapeptide fragment under alkaline conditions. The structure of the synthesized cyclooligopeptide was confirmed using quantitative elemental analysis, FTIR (Fourier-transform infrared spectroscopy), ${ }^{1} \mathrm{H}$ NMR (Nuclear magnetic resonance spectroscopy), ${ }^{13} \mathrm{C}$ NMR, and mass spectrometry. From the bioactivity results, it was clear that the newly synthesized proline-rich tetracyclopeptide exhibited better anthelmintic potential against Megascoplex konkanensis, Pontoscotex corethruses, and Eudrilus eugeniae at a concentration of $2 \mathrm{mg} / \mathrm{mL}$ as well as improved antifungal activity against pathogenic dermatophytes Trichophyton mentagrophytes and Microsporum audouinii at a concentration of $6 \mu \mathrm{g} / \mathrm{mL}$, as compared to non-methylated tetracyclopeptide. Moreover, $\mathrm{N}$-methylated tetracyclopeptide displayed significant activity against pathogenic Candida albicans.
\end{abstract}

Keywords: N-methylation; tetracyclopeptide; Pseudomonas sp.; macrocyclization; marine sponge; Pseudoalteromonas sp.; solution-phase peptide synthesis; pharmacological activity

\section{Introduction}

The marine environment is distinguished by unique groups of organisms which are a source of extremely interesting structures with a wide array of biological activities [1]. The enormous 
biodiversity of marine habitats is mirrored by the molecular diversity of secondary metabolites found to be associated with marine sponges, bacteria, fungi, mollusks, etc. Among these metabolites, cyclopeptides have emerged as a unique group of bioactive analogs with interesting pharmacological and biochemical properties including cytotoxicity [2-4], insecticidal activity [5], antimicrobial activity [6,7], antitubercular activity [8], anti-inflammatory activity [9], Human Immunodeficiency Virus (HIV)-inhibitory activity [10], chymotrypsin-inhibitory activity [11], antimalarial activity [12], etc. Among cyclooligopeptides, $\mathrm{N}$-methylated peptides have attracted the attention of researchers and scientists in terms of their unique structures and diverse pharmacological activities $[13,14]$. Evolutionarily speaking, nature has employed the $N$-methylation of peptides as an ingenious technique to modulate biological function [15]. The $N$-methylation of amino acids and their derivatives can be carried out with dimethyl sulfate in the presence of sodium hydride and a catalytic amount of water [16], by utilizing 2-chlorotrityl chloride resin/nosyl group and diazomethane [17], by the reductive amination, and via other novel methods [18]. In recent years, through the advancement in synthetic approaches, the potential of $\mathrm{N}$-methylation has begun to be revealed in terms of modulating the biological activity, selectivity, and pharmacokinetic properties of peptides, but also in delivering novel drugs $[19,20]$. Many studies have shown the $N$-methylation of the cyclic peptides to offer a number of advantages, including the improvement of the therapeutic efficacy of peptides by fine-tuning their selectivity for a receptor, enhancing the hydrophobicity by reducing the number of hydrogen-bond donors and by preventing the formation of intermolecular and intramolecular hydrogen bonds, which in turn improves the oral bioavailability [21].

Keeping in view the utilization of $N$-methylation in modulating the biological properties of peptides and, further, in continuation of the efforts of our research group in the synthesis of bioactive cyclic peptides [14,22-25], the present study was directed toward the first total synthesis of an $N$-methylated analog of a natural tetracyclopeptide. The non-methylated natural peptide was previously isolated from the marine bacteria Pseudomonas sp. and Pseudoalteromonas sp., associated with the seaweed Diginea sp. and the sponge Halisarca ectofibrosa [26]. Further, the newly synthesized $\mathrm{N}$-methylated peptide was subjected to antibacterial, antifungal, antidermatophytic, and anthelmintic screening and its bioproperties were compared with those of the non-methylated analog.

\section{Results}

\subsection{Chemistry}

The solution-phase technique of peptide synthesis was employed to prepare an $N$-methylated analog of a natural tetracyclopeptide. In the present study, $p$-nitrophenol ( $p n p)$ was used for the esterification of a linear tetrapeptide chain and compared with pentafluorophenol ( $p f p)$ during the synthesis of tetracyclopeptide 4, affording it in a 74-89\% yield, utilizing $N$-methylmorpholine and pyridine as bases. There is a literature report indicating the synthesis of non-methylated natural cyclic tetrapeptide employing the solution-phase technique [27], an $\mathrm{N}$-methylated analog of which was selected for synthesis in the present investigation. In this study, the peptide units were prepared by the Bodanszky and Bodanszky method with certain modifications [28]. Prior to coupling, the amino groups of L-amino acids were protected using Di-tert-butyl dicarbonate $\left(\mathrm{Boc}_{2} \mathrm{O}\right)$ and the deprotection of amino groups was achieved using trifluoroacetic acid (TFA). Similarly, the carboxyl groups of L-amino acids were protected by an esterification reaction with Methanol in the presence of Chlorotrimethylsilane and the deprotection of carboxyl groups was realized by alkaline hydrolysis with lithium hydroxide $(\mathrm{LiOH})$. Racemization was avoided by the utilization of 1-Hydroxybenzotriazole (HOBt) in all coupling reactions.

In order to carry out the synthesis of $N$-methylated tetracyclopeptide, Boc-amino acid viz. Boc-L-Pro-OH was coupled with the corresponding $N$-methylated amino acid methyl esters such as L-N-(Me)Leu-OMe and L-N-(Me)Phe-OMe. The required amino acid methyl ester hydrochloride, such as L-Leu-OMe-HCl, L-Phe-OMe- $\mathrm{HCl}$, and Boc-protected amino acid viz. Boc-L-Pro-OH, were 
prepared according to previously reported procedures in the literature [29]. The free $\mathrm{NH}_{2}$ groups of L-Leu-OMe $\cdot \mathrm{HCl}$ and L-Phe-OMe $\cdot \mathrm{HCl}$ were protected by the introduction of Boc-groups producing Boc-L-Leu-OMe and Boc-L-Phe-OMe, respectively. The $N$-methylation of Boc-protected leucine and phenylalanine methyl ester was achieved by treatment with methyl iodide and sodium hydride [30], producing Boc-L-N-(Me)Leu-OMe and Boc-L-N-(Me)Phe-OMe. The Boc-groups of the resulting units were removed using TFA producing L-N-(Me)Leu-OMe and L-N-(Me)Phe-OMe, respectively. The required dipeptide units Boc-L-Pro-L-N-(Me)Leu-OMe (1) and Boc-L-Pro-L-N-(Me)Phe-OMe (2) were prepared by the coupling of $N$-methylated leucine and phenylalanine methyl esters with Boc-L-Pro-OH, employing DCC/EDC. $\mathrm{HCl}$ as the coupling agent and TEA as the base. The ester group of the dipeptide unit Boc-L-Pro-L-N-(Me)Leu-OMe was removed by alkaline hydrolysis with $\mathrm{LiOH}$ and the deprotected peptide was coupled with another dipeptide unit Boc-L-Pro-L-N-(Me)Phe-OMe after deprotection at the amino terminal, producing the linear tetrapeptide unit Boc-L-Pro-L-N-(Me)Leu-L-Pro-L-N-(Me)Phe-OMe (3). The methyl ester group of the linear peptide fragment was replaced by a $p$-nitrophenyl ( $p n p) /$ pentafluorophenyl ( $p f p$ ) ester group. The Boc-group of the resulting compound was removed using TFA and the deprotected linear fragment was then cyclized by maintaining the entire content at $0{ }^{\circ} \mathrm{C}$ for 7 days in the presence of catalytic amounts of NMM or pyridine, producing cyclo(L-Pro-L-N-(Me)Leu-L-Pro-L-N-(Me)Phe) (4). The structure of the newly synthesized tetracyclopeptide as well as that of the intermediate di- and tetrapeptides were confirmed by FT-IR, ${ }^{1} \mathrm{H} /{ }^{13} \mathrm{C}$ NMR spectroscopy, and elemental analysis. In addition, mass spectrum was recorded for the $\mathrm{N}$-methylated cyclic product 4 . The synthetic pathway for the newly synthesized tetracyclopeptide is given in Figure 1.<smiles>CC(C)(C)OC(=O)N1CCCC1C(=O)O</smiles><smiles>CNC(CC(C)C)C(=O)OC</smiles><smiles>COC(=O)C(CC(C)C)N(C)C(=O)C1CCCN1C(=O)OC(C)(C)C</smiles><smiles>CC(C)(C)OC(=O)N1CCCC1C(=O)O</smiles><smiles>CNC(Cc1ccc(C)cc1)C(=O)OC</smiles><smiles>CC1CC2C(=O)N3CCCC3C(=O)N3Cc4ccccc4CC3C(=O)N3CCCC3C(=O)N2C1</smiles>

4<smiles>CC(C)(C)O</smiles>

, e

$<1$
2

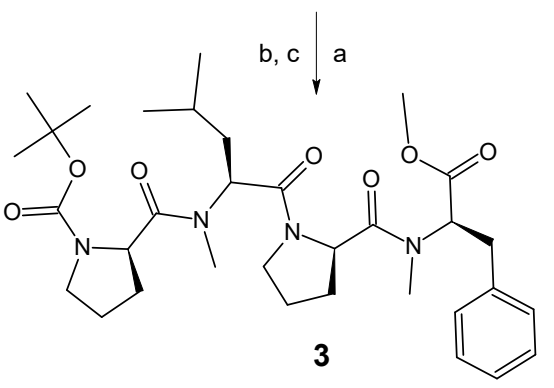

a: DCC/EDC.HCl, TEA/NMM, HOBt, DCM/THF, RT, 24 h; b: LiOH, THF:H $2 \mathrm{O}(1: 1), \mathrm{RT}, 1$ h;

c: TFA, $\mathrm{CHCl}_{3}, \mathrm{RT}, 1 \mathrm{~h}$; d: DIPC, pnp/pfp, $\mathrm{CHCl}_{3}, \mathrm{RT}, 12 \mathrm{~h}$; e: $\mathrm{NMM} / \mathrm{C}_{5} \mathrm{H}_{5} \mathrm{~N}, \mathrm{CHCl}_{3}, 7$ days, $0^{\circ} \mathrm{C}$

Figure 1. Synthetic route for $N$-methylated proline-rich tetracyclopeptide 4. 1. Boc-L-Pro-L-N-(Me)Leu-OMe; 2. Boc-L-Pro-L-N-(Me)Phe-OMe; 3. Boc-L-Pro-L-N-(Me)Leu-L-Pro-L-N- (Me)Phe-OMe; and 4. cyclo(L-ProL-N-(Me)Leu-L-Pro-L-N-(Me)Phe). 


\subsection{Pharmacological Activity}

The anthelmintic screening of linear and cyclic tetracyclopeptides $(3,4)$ was performed against three earthworm species (Megascoplex konkanensis, Pontoscotex corethruses, and Eudrilus eugeniae) at a concentration of $2 \mathrm{mg} / \mathrm{mL}$ using the modified Garg's method [31]. The bioactivity results are presented in Table 1. Further, antibacterial and antifungal evaluations of peptides 3, 4 were conducted against four Gram-positive and Gram-negative bacteria-Bacillus subtilis and Staphylococcus aureus, Pseudomonas aeruginosa and Klebsiella pneumoniae, respectively; dermatophytes Microsporum audouinii and Trichophyton mentagrophytes; and diamorphic fungi Candida albicans and Aspergillus niger using the modified Kirby-Bauer disk diffusion method [32]. The antimicrobial activity results are compiled in Table 2.

Table 1. Anthelmintic activity data for the proline-rich linear and cyclic tetracyclopeptides 3, 4 .

\begin{tabular}{|c|c|c|c|c|c|c|}
\hline \multirow{3}{*}{ Compound $^{\partial}$} & \multicolumn{6}{|c|}{ Earthworm Species } \\
\hline & \multicolumn{2}{|c|}{ M. kon. } & \multicolumn{2}{|c|}{ P. cor. } & \multicolumn{2}{|c|}{ E. eug. } \\
\hline & $\begin{array}{c}\text { Mean } \\
\text { Paralyzing } \\
\text { Time (min) }\end{array}$ & $\begin{array}{l}\text { Mean Death } \\
\text { Time }(\min ) ~\end{array}$ & $\begin{array}{c}\text { Mean } \\
\text { Paralyzing } \\
\text { Time (min) }\end{array}$ & $\begin{array}{l}\text { Mean Death } \\
\text { Time (min) }\end{array}$ & $\begin{array}{c}\text { Mean } \\
\text { Paralyzing } \\
\text { Time (min) }\end{array}$ & $\begin{array}{l}\text { Mean Death } \\
\text { Time (min) }\end{array}$ \\
\hline III * & $14.06 \pm 0.36$ & $22.09 \pm 0.27$ & $18.55 \pm 0.19$ & $29.44 \pm 0.29$ & $14.15 \pm 0.26$ & $24.32 \pm 0.36$ \\
\hline IV * & $10.25 \pm 0.22$ & $18.22 \pm 0.14$ & $12.36 \pm 0.37$ & $21.25 \pm 0.14$ & $12.34 \pm 0.41$ & $21.04 \pm 0.21$ \\
\hline 3 & $13.43 \pm 0.22$ & $21.13 \pm 0.49$ & $17.08 \pm 0.16$ & $27.16 \pm 0.22$ & $12.57 \pm 0.33$ & $22.08 \pm 0.25$ \\
\hline 4 & $08.12 \pm 0.41$ & $16.45 \pm 0.26$ & $09.55 \pm 0.29$ & $20.05 \pm 0.44$ & $09.50 \pm 0.24$ & $18.05 \pm 0.39$ \\
\hline Control $\#$ & - & - & - & - & - & - \\
\hline Mebendazole & $13.58 \pm 0.38$ & $22.59 \pm 0.29$ & $17.58 \pm 0.40$ & $29.56 \pm 0.15$ & $13.50 \pm 0.44$ & $24.09 \pm 0.49$ \\
\hline
\end{tabular}

M. kon.: Megascoplex konkanensis; P. cor: Pontoscotex corethruses; E. eug.: Eudrilus eugeniae. ${ }^{\ddagger}$ Data are given as mean \pm S.D. $(n=3) .{ }^{*}$ Bioactivity data for III, IV (non-methylated compounds) were obtained under the same experimental conditions as those used for methylated derivatives and compared with the results of a previously published report [27]. ${ }^{\#}$ Tween $80(0.5 \%)$ in distilled water. ${ }^{\text {O }}$ Compounds were tested at a concentration of $2 \mathrm{mg} / \mathrm{mL}$.

Table 2. Antimicrobial activity data for proline-rich linear and cyclic tetracyclopeptides 3, 4.

\begin{tabular}{|c|c|c|c|c|c|c|c|c|}
\hline \multirow{3}{*}{ Compound $^{\partial}$} & \multicolumn{8}{|c|}{ Diameter of Zone of Inhibition (mm) } \\
\hline & \multicolumn{4}{|c|}{ Bacterial Strains } & \multicolumn{4}{|c|}{ Fungal Strains } \\
\hline & B. sub. & S. aur. & P. aer. & K. pne. & C. alb. & M. aud. & A. nig. & T. men. \\
\hline III * & - & - & $12(25)^{\dagger}$ & $17(25)$ & $9(12.5)$ & $17(6)$ & - & $18(6)$ \\
\hline IV * & - & - & $16(25)$ & $19(25)$ & 13 (12.5) & $25(6)$ & - & $26(6)$ \\
\hline 3 & - & $10(12.5)$ & $16(12.5)$ & 18 (12.5) & $18(6)$ & $19(6)$ & - & $22(6)$ \\
\hline 4 & - & 12 (12.5) & 21 (12.5) & $23(12.5)$ & $24(6)$ & 27 (6) & - & $28(6)$ \\
\hline Control $\#$ & - & - & - & - & - & - & - & - \\
\hline Gatifloxacin & $18(12.5)^{\dagger}$ & $27(6)$ & $23(6)$ & $26(6)$ & - & - & - & - \\
\hline Griseofulvin & - & - & - & - & $20(6)$ & $18(6)$ & $20(12.5)$ & $19(6)$ \\
\hline
\end{tabular}

\section{Discussion}

The synthesis of an $\mathrm{N}$-methylated cyclooligopeptide (4) was accomplished with an $89 \%$ yield, and NMM proved to be an effective base for the cyclization of the linear tetrapeptide segment in comparison to TEA and pyridine. Cyclization was supported by the disappearance of absorption bands at 1742,1273 and $1395,1373 \mathrm{~cm}^{-1}$ due to $\mathrm{C}=\mathrm{O}_{\text {str }}, \mathrm{C}-\mathrm{O}_{\text {str }}$, ester, and $\mathrm{C}-\mathrm{H}_{\text {def }}$, tert-butyl groups in the IR spectra of compound 4 . The formation of the cyclopeptide was further confirmed by the disappearance of singlets at 3.54 and $1.52 \mathrm{ppm}$, corresponding to three protons of the methyl ester group and nine 
protons of the tert-butyl group of Boc in the ${ }^{1} \mathrm{H}$ NMR spectrum, in addition to the disappearance of the singlets at 155.4, 80.4 and 53.0, $29.6 \mathrm{ppm}$, corresponding to carbon atoms of tert-butyl and ester groups in the ${ }^{13} \mathrm{C}$ NMR spectrum of compound 4. Furthermore, the ${ }^{1} \mathrm{H}$ NMR and ${ }^{13} \mathrm{C}$ NMR spectra of the synthesized $N$-methylated tetracyclopeptide showed characteristic peaks confirming the presence of all 38 protons and 27 carbon atoms. The pseudomolecular ion peak $(\mathbf{M}+1)^{+}$appearing at $\mathrm{m} / z=483$ corresponded to the molecular formula $\mathrm{C}_{27} \mathrm{H}_{38} \mathrm{~N}_{4} \mathrm{O}_{4}$ in the mass spectrum of 4 , along with other fragment ion peaks resulting from the cleavage at 'N(Me)Leu-Pro', 'Pro- $N(\mathrm{Me}) \mathrm{Phe}^{\prime}$, 'N(Me)Phe-Pro', and 'Pro-N(Me)Leu' amide bonds (Figure 2). In addition, the presence of the immonium ion peaks at $m / z=134$ [N(Me)Phe], 100 [N(Me)Leu], and 70 [Pro] further confirmed all of the amino acid moieties in the cyclopeptide structure. Furthermore, the elemental analysis of tetracyclopeptide 4 afforded values with a strict tolerance of \pm 0.03 , in accordance with the molecular composition.
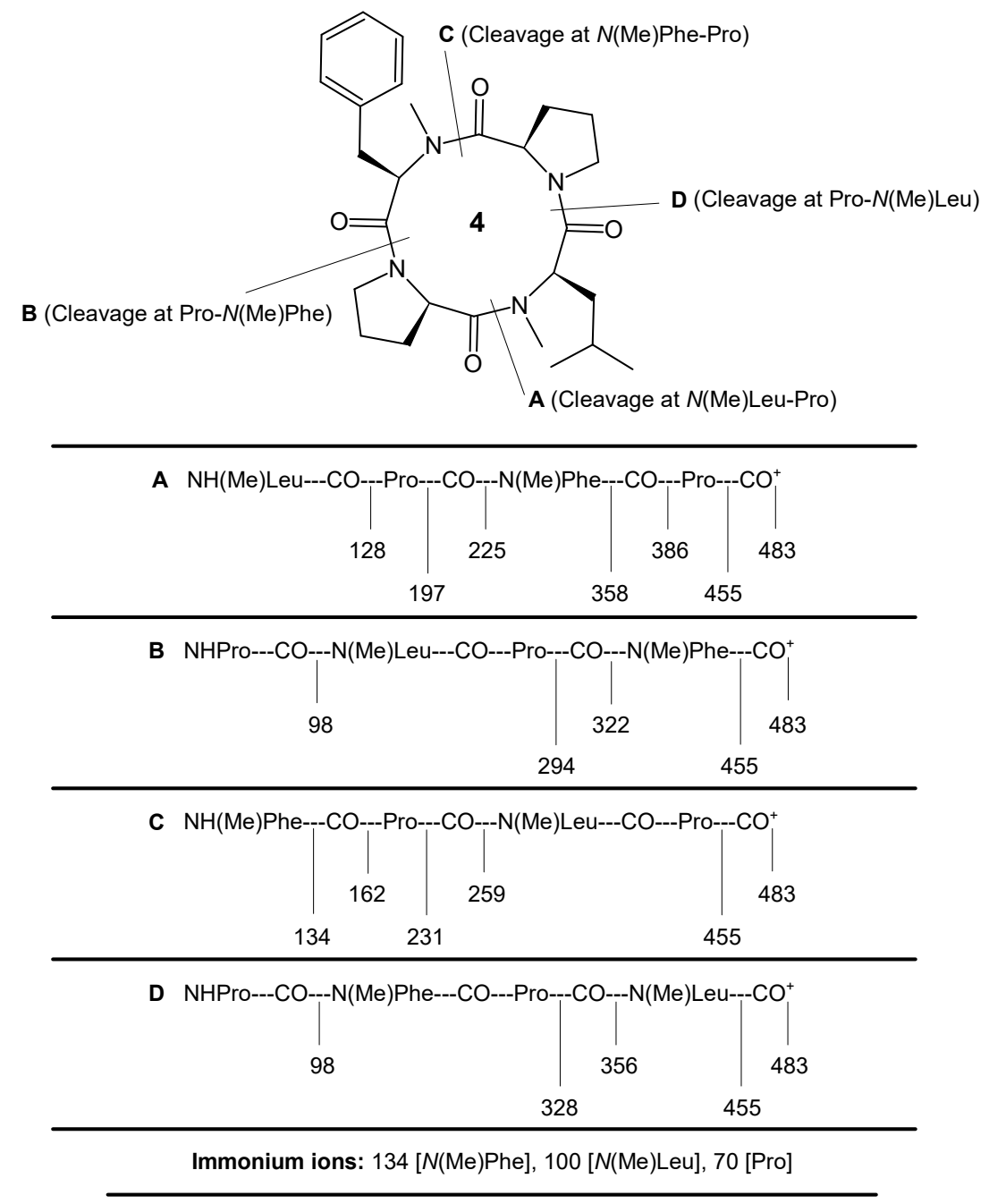

Figure 2. Fragmentation pattern for $\mathrm{N}$-methylated proline-rich tetracyclopeptide 4 at diverse amide bond levels.

In the present study, we observed that the proline-rich tetracyclopeptide 4 exhibits better anthelmintic activity than the standard drug Mebendazole at a concentration of $2 \mathrm{mg} / \mathrm{mL}$ against all three of the tested earthworm species. Comparison of antimicrobial activity data suggested that $\mathrm{N}$-methylated tetracyclopeptide 4 possesses potent bioactivity against dermatophytes $M$. audouinii, T. mentagrophytes and pathogenic fungi $C$. albicans with minimum inhibitory concentration (MIC) values of $6 \mu \mathrm{g} / \mathrm{mL}$ when compared to the reference drug Griseofulvin. Moreover, moderate activity was seen 
against Gram-negative bacteria P. aeruginosa and K. pneumonia for the newly synthesized N-methylated tetracyclopeptide, in comparison to the standard drug Gatifloxacin. However, compound 4 displayed little activity against Gram-positive bacteria $S$. aureus but no significant activity against $B$. subtitis nor $A$. niger. In addition, the analysis of the pharmacological activity data revealed that proline-rich $\mathrm{N}$-methylated tetracyclopeptide 4 displayed higher bioactivity against pathogenic microbes and earthworms than its linear form, 3, which is due to the fact that the cyclization of the peptides reduces the degree of freedom for each constituent within the ring and thus substantially leads to the reduced flexibility, as well as increased potency and selectivity of the cyclic peptide [33]. Further, comparison of biological activity data of compound 4 with its non- $N$-methylated analog IV, previously synthesized by our research group [27], suggested that proline-rich $N$-methylated tetracyclopeptide 4 displayed improved pharmacological activity against pathogenic dermatophytes, earthworms, and Gram-negative bacteria than its non- $N$-methylated analog IV, which is due to the fact that $\mathrm{N}$-methylation is the simplest chemical modification occurring in peptides and proteins to improve the potency. In particular, better improvement was observed in the antifungal activity of compound 4 against pathogenic $C$. albicans in comparison to its non- $N$-methylated analog IV.

Detailed investigation of the structures and biological potential of naturally occurring cyclooligopeptides suggested that there are various natural cyclic peptides in the literature rich in proline units which have shown biological potential [4]. In most instances, the arrangement of two proline units was found to be alternate to each other, as was also observed in the cyclopeptide chosen for the present study. Besides this, the same type of arrangement of two proline units has been found in the natural/synthetic cyclopeptide 'Hymenamide E', which has already shown potent anthelmintic and antifungal effects [29]. This arrangement of two proline units in a cyclic structure in an alternate pattern appears to be responsible for the biological potential of the tetracyclopeptide.

The possible mechanism of action for antimicrobial activity of $N$-methylated proline-rich tetracyclopeptides may involve the active transport inside the bacterial cell where peptides can bind and inactivate the specific targets such as the bacterial ribosome and inhibit protein synthesis, similar to other proline-rich antimicrobial peptides [34]. Antifungal activity may be attributed to the inhibition of chitin synthesis, which is a cell wall component essential to the maintenance of the structural integrity of the fungus; the inhibition of 1-3 $\beta$ glucan synthase, a multiunit membrane-integrated enzyme which is critical to cell wall integrity; and the ability to traverse the energized membrane and interact with an intracellular target or incite the intracellular induction of reactive oxygen species (ROS), which are toxic to the fungi, as reported for the established anti-fungal peptides [35].

Dermatophytes such as Microsporum and Trichophyton are the prevailing causes of fungal infection of the skin, hair, and nails due to their ability to utilize keratin. They are also responsible for athlete's foot. In temperate regions, foot ringworm (athlete's foot) accounts for $75 \%$ of all tinea diseases. These dermatophytes grow in the non-living tissues of hair, nails, and skin, in the region above the layers where keratin is deposited, and cause a complex of diseases known clinically as tinea (ringworm) in humans and other vertebrates [36,37]. The zoophilic fungi, such as M. audouinii, more commonly affect children and tend to evoke a more acute inflammatory response than do the anthropophilic fungi. Besides this, T. mentagrophytes is among the most common dermatophytes responsible for infections [38]. Candida albicans and other Candida species can cause cutaneous infections at many sites on the body, especially those that are moist, such as folds of flesh and armpits. Candida can cause a different and serious disease if the cells enter and spread within the body [37]. Further, K. pneumoniae is an opportunistic pathogen that can cause severe hospital-acquired infections such as septicaemia, pneumonia, urinary tract infection, and soft tissue infection. It is frequently found in the flora of the mouth, skin, and intestines [39]. Another Gram-negative bacterium, P. aeruginosa, has emerged as an important pathogen which causes between $10 \%$ and $20 \%$ of infections in most hospitals. Pseudomonas infection is especially prevalent among patients with burn wounds, cystic fibrosis, acute leukemia, organ transplants, and intravenous-drug addiction [40]. 
As per the literature, and despite its apparent simplicity, Caenorhabditis elegans has developed into an important model for biomedical research, particularly in the functional characterization of novel drug targets. Models of the nematode worm C. elegans can be used to advance the understanding of the molecular mechanisms of drug action and disease pathogenesis. Several features of $C$. elegans - as it is easy to culture; undergoes rapid reproduction with a short generation time, enabling the large-scale production of animals; has a small size; is transparent, which enables the use of fluorescent markers to study biological processes in vivo; and exhibits cellular complexity-make it a powerful tool for the pharmaceutical industry [41]. Using mutant strains, RNA interference (RNAi), and passive optical techniques, C. elegans can be used as an early model to evaluate mechanisms and pathways that formerly would have required more expensive and time-consuming methods. Further, spectroscopic techniques for C. elegans are also valuable preliminary tools for finding novel developmental disruptors, anthelminthic agents, neurotransmitter agonists/antagonists, and proteasome regulators [42].

\section{Materials and Methods}

The melting point was determined by the open capillary method and is uncorrected. The FTIR spectra for all of the synthesized compounds were recorded using an FTIR-8400S Fourier transform spectrophotometer (Shimadzu, Kyoto, Japan). The ${ }^{1} \mathrm{H}$ NMR and ${ }^{13} \mathrm{C}$ NMR spectra of the tetracyclopeptide and intermediate linear peptide units were recorded on a Bruker AC 300 spectrometer at $300 \mathrm{MHz}$ (Brucker, IL, USA). The mass spectra of $\mathrm{N}$-methylated tetracyclopeptide were recorded on a JMS-DX 303 spectrometer (Jeol, Tokyo, Japan). The elemental analysis was performed on a Vario EL III elemental analyzer (Elementar Vario EL III, Hanau, Germany). The optical rotation was measured on an Optics Technology automatic polarimeter (Optics Technology, Delhi, India). The purity of the synthesized tetracyclopeptide and the intermediate linear peptide units was checked by Thin Layer Chromatography (TLC) on precoated silica gel G plates (Kieselgel 0.25 mm, 60G F 254 , Merck, Germany).

\subsection{Procedure for the Preparation of N-Methylated Dipeptide Units $(\mathbf{1}, \mathbf{2})$}

The $N$-methylated-L-amino acid methyl ester (L-N-(Me)Leu-OMe $(1.59 \mathrm{~g}, 0.01 \mathrm{~mol}))$ was dissolved in Dichloromethane (DCM, $30 \mathrm{~mL})$. To this, TEA $(2.8 \mathrm{~mL}, 0.021 \mathrm{~mol})$ was added at $0{ }^{\circ} \mathrm{C}$ and the reaction mixture was stirred for $15 \mathrm{~min}$. Boc-L-Pro-OH ( $2.15 \mathrm{~g}, 0.01 \mathrm{~mol})$ was dissolved in DCM (30 mL) followed by the addition of DCC $(2.12 \mathrm{~g}, 0.01 \mathrm{~mol})$ and $\mathrm{HOBt}(1.34 \mathrm{~g}, 0.01 \mathrm{~mol})$. The resulting mixture was added to the above solution with constant shaking and stirring was continued for $24 \mathrm{~h}$. This reaction was repeated using EDC. $\mathrm{HCl}(1.92 \mathrm{~g}, 0.01 \mathrm{~mol})$ as the coupling agent instead of DCC. The reaction mixture was filtered and the residue was washed with DCM $(25 \mathrm{~mL})$ and added to the filtrate. The filtrate was washed with $5 \% \mathrm{NaHCO}_{3}$ and saturated $\mathrm{NaCl}$ solutions. The organic layer was dried over anhydrous $\mathrm{Na}_{2} \mathrm{SO}_{4}$, filtered, and evaporated in vacuum. The crude product was recrystallized from a mixture of chloroform and petroleum ether (Boiling point (b.p.) $40-60^{\circ} \mathrm{C}$ ) followed by cooling at $0{ }^{\circ} \mathrm{C}$ to obtain the title compound Boc-L-Pro-L-N-(Me)Leu-OMe (1). Similarly, the $N$-methylated dipeptide unit Boc-L-Pro-L-N-(Me)Phe-OMe (2) was prepared by coupling L- $N$-(Me)Phe-OMe (1.93 g, $0.01 \mathrm{~mol})$ and Boc-L-Pro-OH (2.15 g, $0.01 \mathrm{~mol})$ under similar conditions.

\subsection{1. tert-Butyloxycarbonyl-L-Prolyl-L-N-Methyl-L-Leucine Methyl Ester (1)}

Semisolid mass; yield 79\%; $[\alpha]_{\mathrm{D}}=-32.1^{\circ}(c=0.25, \mathrm{MeOH}) ; \mathrm{R}_{f}=0.62\left(\mathrm{CHCl}_{3} \cdot \mathrm{MeOH}-8: 2\right) ; \mathrm{IR}$ $\left(\mathrm{CHCl}_{3}\right): v=2995-2988$ (C-Hstr), 2966, 2927 (C-Hstr), 2796 (C-Hstr N-Me), $1744\left(\mathrm{C}=\mathrm{O}_{\text {str }}\right), 1677,1638$ $\left(\mathrm{C}=\mathrm{O}_{\text {str }}\right), 1398,1373$ (C-Hdef), 1388, 1367 (C-Hdef), 1269 (C-Ostr) $\mathrm{cm}^{-1} ;{ }^{1} \mathrm{H} \mathrm{NMR}\left(\mathrm{CDCl}_{3}\right): \delta=4.52$ $(\mathrm{t}, J=6.1 \mathrm{~Hz}, 1 \mathrm{H}, \mathrm{H}-\alpha, \mathrm{Leu}), 4.10(\mathrm{t}, J=7.15 \mathrm{~Hz}, 1 \mathrm{H}, \mathrm{H}-\alpha$, Pro $), 3.65\left(\mathrm{~s}, 3 \mathrm{H}, \mathrm{OCH}_{3}\right), 3.25(\mathrm{t}, J=7.2 \mathrm{~Hz}$, 2H, H- $\delta$, Pro), 2.99 (s, 3H, NCH 3 ), 2.57 (q, J = $5.65 \mathrm{~Hz}, 2 \mathrm{H}, \mathrm{H}-\beta$, Pro), 1.96-1.88 (m, 2H, H- $\gamma$, Pro), 1.49 (s, 9H, tert-Butyl), 1.45-1.34 (m, 3H, H- $\beta$ and H- $\gamma$, Leu), $0.94(\mathrm{~d}, 6 \mathrm{H}, J=6.35 \mathrm{~Hz}, \mathrm{H}-\delta, \mathrm{Leu}) ;{ }^{13} \mathrm{C}$ NMR $\left(\mathrm{CDCl}_{3}\right): \delta=176.4(\mathrm{C}=\mathrm{O}$, Pro $), 170.3(\mathrm{C}=\mathrm{O}, \mathrm{Leu}), 159.8(\mathrm{C}=\mathrm{O}, \mathrm{Boc}), 79.4$ (C- $\alpha$, tert-Butyl), 60.7 (C- $\alpha$, Pro), $55.9(\mathrm{C}-\alpha, \mathrm{Leu}), 54.2\left(\mathrm{OCH}_{3}\right), 46.7(\mathrm{C}-\delta, \mathrm{Pro}), 40.7(\mathrm{C}-\beta, \mathrm{Leu}), 35.3\left(\mathrm{NCH}_{3}\right), 30.4(\mathrm{C}-\beta, \mathrm{Pro}), 29.1$ (3C, C- $\beta$, 
tert-Butyl), 26.6, 24.1 (2C, C- $\gamma$, Leu and Pro), 21.8 (2C, C- $\delta$, Leu); $\mathrm{C}_{18} \mathrm{H}_{32} \mathrm{~N}_{2} \mathrm{O}_{5}$ (356): calcd. C 60.65, H 9.05, N 7.86; found C 60.66, H 9.02, N 7.88.

\subsection{2. tert-Butyloxycarbonyl-L-Prolyl-L-N-Methyl-Phenylalanine Methyl Ester (2)}

Semisolid mass; yield 81\%; $[\alpha]_{\mathrm{D}}=+44.9^{\circ}(c=0.25, \mathrm{MeOH}) ; \mathrm{R}_{f}=0.48\left(\mathrm{CHCl}_{3} \cdot \mathrm{MeOH}-8: 2\right) ; \mathrm{IR}$ $\left(\mathrm{CHCl}_{3}\right): v=2996-2987$ (C-Hstr), 2965, 2929, 2877 (C-Hstr), 2802 (C-Hstr N-Me), $1741\left(\mathrm{C}=\mathrm{O}_{\text {str }}\right), 1672$, 1636 (C=Ostr), 1544, 1415 (C=C), 1389, 1377 (C-Hdef), 1273 (C-Ostr), 725, 686 (C-Hdef) cm ${ }^{-1}$; ${ }^{1} \mathrm{H}$ NMR $\left(\mathrm{CDCl}_{3}\right): \delta=7.15(\mathrm{t}, J=5.65 \mathrm{~Hz}, 1 \mathrm{H}, \mathrm{H}-p, \mathrm{Phe}), 7.05-6.97(\mathrm{~m}, 2 \mathrm{H}, \mathrm{H}-m, \mathrm{Phe}), 6.76(\mathrm{dd}, J=5.8 \mathrm{~Hz}$, $7.15 \mathrm{~Hz}, 2 \mathrm{H}, \mathrm{H}-\mathrm{o}, \mathrm{Phe}), 5.16$ (t, $J=5.65 \mathrm{~Hz}, 1 \mathrm{H}, \mathrm{H}-\alpha$, Phe), 4.11 (t, $J=6.45 \mathrm{~Hz}, 1 \mathrm{H}, \mathrm{H}-\alpha$, Pro), 3.54 (s, 3H, $\left.\mathrm{OCH}_{3}\right), 3.21(\mathrm{t}, J=7.15 \mathrm{~Hz}, 2 \mathrm{H}, \mathrm{H}-\delta, \mathrm{Pro}), 3.09(\mathrm{~d}, J=4.85 \mathrm{~Hz}, 2 \mathrm{H}, \mathrm{H}-\beta, \mathrm{Phe}), 3.05\left(\mathrm{~s}, 3 \mathrm{H}, \mathrm{NCH}_{3}\right), 2.57$ (q, J $=5.45 \mathrm{~Hz}, 2 \mathrm{H}, \mathrm{H}-\beta$, Pro), 1.92-1.86 (m, 2H, H- $\gamma$, Pro), 1.46 (s, 9H, tert-Butyl); ${ }^{13} \mathrm{C}$ NMR $\left(\mathrm{CDCl}_{3}\right)$ : $\delta=175.4,170.1$ (2C, C=O, Pro and Phe), 159.7 (C=O, Boc), 138.8 (C- $\gamma$, Phe), 130.2 (2C, C-o, Phe), 127.6 (2C, C- $m$, Phe), 126.2 (C- $p$, Phe), 80.3 (C- $\alpha$, tert-Butyl), 62.7, 59.3 (2C, C- $\alpha$, Pro and Phe), $53.8\left(\mathrm{OCH}_{3}\right)$, 46.9 (C- $\delta$, Pro), 34.9, 32.7 (2C, C- $\beta$, Phe and Pro), $32.1\left(\mathrm{NCH}_{3}\right), 29.5$ (3C, C- $\beta$, tert-Butyl), 24.0 (C- $\gamma$, Pro); $\mathrm{C}_{21} \mathrm{H}_{30} \mathrm{~N}_{2} \mathrm{O}_{5}$ (390): calcd. C 64.60, H 7.74, N 7.17; found C 64.59, H 7.71, N 7.19.

\subsection{Procedure for the Synthesis of Linear Tetrapeptide Segments (3)}

To the solution of the dipeptide methyl ester, L-Pro-L-N-(Me)Phe-OMe $(2.90 \mathrm{~g}, 0.01 \mathrm{~mol})$ in tetrahydrofuran (THF, $25 \mathrm{~mL}), \mathrm{NMM}(2.23 \mathrm{~mL}, 0.021 \mathrm{~mol})$ was added at $0{ }^{\circ} \mathrm{C}$, and the reaction mixture was stirred for $25 \mathrm{~min}$. To a solution of Boc-L-Pro-L-N-(Me)Leu-OH ( $3.42 \mathrm{~g}, 0.01 \mathrm{~mol})$ in THF $(25 \mathrm{~mL})$, DCC $(2.12 \mathrm{~g}, 0.01 \mathrm{~mol})$ and HOBt $(1.34 \mathrm{~g}, 0.01 \mathrm{~mol})$ were added with stirring and the resulting mixture was added to the above reaction mixture. The stirring of the resulting mixture was continued for $24 \mathrm{~h}$ at RT. This reaction was repeated using EDC. $\mathrm{HCl}(1.92 \mathrm{~g}, 0.01 \mathrm{~mol})$ as a coupling agent in place of DCC. The reaction mixture was filtered and the residue was washed with THF $(25 \mathrm{~mL})$ and added to the filtrate. The filtrate was washed with $5 \% \mathrm{NaHCO}_{3}$ and saturated $\mathrm{NaCl}$ solutions. The organic layer was dried over anhydrous $\mathrm{Na}_{2} \mathrm{SO}_{4}$, filtered, and evaporated in vacuum. The crude product was recrystallized from a mixture of chloroform and petroleum ether (b.p. $40-60^{\circ} \mathrm{C}$ ) followed by cooling at $0{ }^{\circ} \mathrm{C}$ to obtain the title compound Boc-L-Pro-L-N-(Me) Leu-L-Pro-L-N-(Me)Phe-OMe (3).

tert-Butyloxycarbonyl-L-Prolyl-L-N-Methyl-L-Leucyl-L-Prolyl-L-N-Methyl-Phenylalanine Methyl Ester (3)

Semisolid mass; yield 83\%; $[\alpha]_{\mathrm{D}}=-53.6^{\circ}(c=0.25, \mathrm{MeOH}) ; \mathrm{R}_{f}=0.82\left(\mathrm{CHCl}_{3} \cdot \mathrm{MeOH}-7: 3\right) ; \mathrm{IR}$ $\left(\mathrm{CHCl}_{3}\right): v$ 2997-2986 (C-Hstr), 2962, 2925-2921, 2875 (C-Hstr), 2801-2794 (C-Hstr N-Me), 1742 (C=Ostr), 1676, 1645-1640 (C=O str ), 1544, 1418 (C=C), 1395, 1373 (C-Hdef), 1386, 1362 (C-Hdef), 1273

(C-Ostr), 729, 684 (C-Hdef) $\mathrm{cm}^{-1} ;{ }^{1} \mathrm{H}$ NMR $\left(\mathrm{CDCl}_{3}\right): \delta=7.19(\mathrm{t}, J=5.65 \mathrm{~Hz}, 1 \mathrm{H}, \mathrm{H}-p$, Phe $), 7.02-6.95$ (m, 2H, H-m, Phe), 6.72 (dd, J = 5.75 Hz, 7.1 Hz, 2H, H-o, Phe), 5.38 (t, $J=5.55 \mathrm{~Hz}, 1 \mathrm{H}, \mathrm{H}-\alpha$, Phe), 4.45 $(\mathrm{t}, J=7.15 \mathrm{~Hz}, 1 \mathrm{H}, \mathrm{H}-\alpha$, Pro-2), $4.36(\mathrm{t}, J=6.15 \mathrm{~Hz}, 1 \mathrm{H}, \mathrm{H}-\alpha, \mathrm{Leu}), 3.95(\mathrm{t}, J=7.15 \mathrm{~Hz}, 1 \mathrm{H}, \mathrm{H}-\alpha$, Pro-1), $3.68\left(\mathrm{t}, J=7.2 \mathrm{~Hz}, 2 \mathrm{H}, \mathrm{H}-\delta\right.$, Pro-2), $3.54\left(\mathrm{~s}, 3 \mathrm{H}, \mathrm{OCH}_{3}\right), 3.24$ (t, $J=7.15 \mathrm{~Hz}, 2 \mathrm{H}, \mathrm{H}-\delta$, Pro-1), 3.09 (d, $J=4.75 \mathrm{~Hz}, 2 \mathrm{H}, \mathrm{H}-\beta$, Phe), 3.06 (s, 3H, NCH 3$), 2.98\left(\mathrm{~s}, 3 \mathrm{H}, \mathrm{NCH}_{3}\right), 2.71$ (q, $J=5.45 \mathrm{~Hz}, 2 \mathrm{H}, \mathrm{H}-\beta$, Pro-2), $2.59(\mathrm{q}, J=5.7 \mathrm{~Hz}, 2 \mathrm{H}, \mathrm{H}-\beta$, Pro-1), 1.98-1.89 (m, 4H, H- $\gamma$, Pro-2 and Pro-1), 1.94-1.83 (m, 3H, H- $\beta$ and $\mathrm{H}-\gamma$, Leu), $1.52\left(\mathrm{~s}, 9 \mathrm{H}\right.$, tert-Butyl), $0.99\left(\mathrm{~d}, J=6.35 \mathrm{~Hz}, 6 \mathrm{H}, \mathrm{H}-\delta\right.$, Leu); ${ }^{13} \mathrm{C} \mathrm{NMR}\left(\mathrm{CDCl}_{3}\right): \delta=175.2,169.3$ (2C, C=O, Pro-2 and Leu), 167.8, 164.4 (2C, C=O, Phe and Pro-1), 155.4 (C=O, Boc), 139.4 (C- $\gamma$, Phe), 129.8 (2C, C-o, Phe), 127.9 (2C, C- $m$, Phe), 126.1 (C- $p$, Phe), 80.4 (C- $\alpha$, tert-Butyl), 59.2 (C- $\alpha$, Leu), 57.5 (C- $\alpha$, Pro-2), 55.7(C- $\alpha$, Pro-1), 53.9 (C- $\alpha$, Phe), $53.0\left(\mathrm{OCH}_{3}\right), 46.2,43.6$ (2C, C- $\delta$, Pro-1 and Pro-2), 36.6 (C- $\beta, \mathrm{Leu}), 33.9\left(\mathrm{NCH}_{3}\right), 33.0,32.3\left(2 \mathrm{C}, \mathrm{C}-\beta\right.$, Phe and Pro-1), $31.7\left(\mathrm{NCH}_{3}\right), 30.8(\mathrm{C}-\beta, \mathrm{Pro}-2), 29.6$ (3C, C- $\beta$, tert-Butyl), 27.2 (C- $\gamma$, Pro-1), 25.5 (2C, C- $\delta$, Leu), 23.9 (C- $\gamma$, Pro-2), $22.2\left(\mathrm{C}-\gamma\right.$, Leu); $\mathrm{C}_{33} \mathrm{H}_{50} \mathrm{~N}_{4} \mathrm{O}_{7}$ (614): calcd. C 64.47, H 8.20, N 9.11; found C 64.45, H 8.19, N 9.14. 


\subsection{Procedure for the Synthesis of N-Methylated Tetracyclopeptide (4)}

The linear tetrapeptide unit, Boc-L-Pro-L-N-(Me)Leu-L-Pro-L-N-(Me)Phe-OMe (3, $3.07 \mathrm{~g}$, $0.005 \mathrm{~mol})$ was deprotected at the carboxyl terminal using $\mathrm{LiOH}(0.18 \mathrm{~g}, 0.0075 \mathrm{~mol})$ to obtain Boc-L-Pro-L-N-(Me)Leu-L-Pro-L-N-(Me)Phe-OH (3a). To a solution of the deprotected tetrapeptide 3a $(3.00 \mathrm{~g}, 0.005 \mathrm{~mol})$ in $\mathrm{CHCl}_{3}(50 \mathrm{~mL})$, p-nitrophenol (pnp, $0.94 \mathrm{~g}, 0.0067 \mathrm{~mol}$ ) and $N, N^{\prime}$-Diisopropylcarbodiimide (DIPC) $(0.63 \mathrm{~g}, 0.005 \mathrm{~mol})$ were added followed by stirring at room temperature for $12 \mathrm{~h}$. The filtrate of the above reaction mixture was washed with $10 \%$ $\mathrm{NaHCO}_{3}(3 \times 25 \mathrm{~mL})$ and $5 \% \mathrm{HCl}(2 \times 25 \mathrm{~mL})$ solutions to obtain the corresponding $p$-nitrophenyl ester. This reaction was repeated using pentafluorophenol (pfp, $1.23 \mathrm{~g}, 0.0067 \mathrm{~mol}$ ) in place of $p$-nitrophenol, producing pentafluorophenyl ester. The Boc-group of the resulting units Boc-L-Pro-L- $N$ (Me)Leu-L-Pro-L-N-(Me)Phe-Opnp (2.89 g, 0.004 mol) / Boc-L-Pro-L-N-(Me)Leu-L-Pro-L-N-(Me)Phe-Opfp $(3.07 \mathrm{~g}, 0.004 \mathrm{~mol})$ was removed using TFA $(0.91 \mathrm{~g}, 0.008 \mathrm{~mol})$ to obtain the deprotected products L-Pro-L-N-(Me)Leu-L-Pro-L-N-(Me)Phe-Opnp/L-Pro-L-N-(Me)Leu-L-Pro-L-N-(Me)Phe-Opfp, which were dissolved in $\mathrm{CHCl}_{3}(20 \mathrm{~mL})$, followed by the addition of TEA/NMM $/ \mathrm{C}_{5} \mathrm{H}_{5} \mathrm{~N}$ $(2.8 \mathrm{~mL} / 2.21 \mathrm{~mL} / 1.61 \mathrm{~mL}, 0.021 \mathrm{~mol})$. Then, all contents were maintained at $0{ }^{\circ} \mathrm{C}$ for 7 days. The reaction mixtures were washed with $10 \% \mathrm{NaHCO}_{3}(3 \times 20 \mathrm{~mL})$ and $5 \% \mathrm{HCl}(2 \times 20 \mathrm{~mL})$ solutions. The organic layer was dried over anhydrous $\mathrm{Na}_{2} \mathrm{SO}_{4}$ and the crude cyclized compound was recrystallized using DCM and $n$-hexane to obtain the pure cyclic product cyclo (L-Pro-L-N-(Me)Leu-L-Pro-L-N-(Me)Phe) (4).

Cyclo (L-Prolyl-L-N-Methyl-L-Leucyl-L-Prolyl-L-N-Methyl-Phenylalanyl) (4)

Pale white solid; m.p. $189-190{ }^{\circ} \mathrm{C}$ (d); yield $89 \%$ (NMM), $78 \%$ (pyridine), $74 \%$ (TEA); $[\alpha]_{\mathrm{D}}=-67.4^{\circ}$ $(c=0.1, \mathrm{MeOH}) ; \mathrm{R}_{f}=0.59\left(\mathrm{CHCl}_{3} \cdot \mathrm{MeOH}-9: 1\right) ; \mathrm{IR}(\mathrm{KBr}): v=2999-2989$ (C-Hstr), 2969, 2925, 2919, 2879 (C-Hstr), 2805-2797 (C-Hstr N-Me), 1674, 1643, 1636-1632 (C=Ostr), 1545, 1411 (C=C), 1382, 1366 (C-Hdef), 726, 688 (C-Hdef) $\mathrm{cm}^{-1},{ }^{1} \mathrm{H}$ NMR $\left(\mathrm{CDCl}_{3}\right): \delta=7.38,7.27$ (dd, J=5.55 Hz, $7.15 \mathrm{~Hz}, 2 \mathrm{H}, \mathrm{H}-m$, Phe), $7.02(\mathrm{t}, J=5.6 \mathrm{~Hz}, 1 \mathrm{H}, \mathrm{H}-p$, Phe), 6.73, 6.64 (dd, $J=5.8 \mathrm{~Hz}, 7.15 \mathrm{~Hz}, 2 \mathrm{H}, \mathrm{H}-\mathrm{o}$, Phe), $5.47(\mathrm{t}, J=6.1 \mathrm{~Hz}$, $1 \mathrm{H}, \mathrm{H}-\alpha, \mathrm{Leu}), 4.97$ (t, $J=5.6 \mathrm{~Hz}, 1 \mathrm{H}, \mathrm{H}-\alpha$, Phe), $4.48(\mathrm{t}, J=7.15 \mathrm{~Hz}, 1 \mathrm{H}, \mathrm{H}-\alpha$, Pro-2), 4.37 (t, $J=7.2 \mathrm{~Hz}$, $1 \mathrm{H}, \mathrm{H}-\alpha$, Pro-1), 3.63 (t, $J=7.2 \mathrm{~Hz}, 2 \mathrm{H}, \mathrm{H}-\delta$, Pro-1), 3.48 (t, $J=7.15 \mathrm{~Hz}, 2 \mathrm{H}, \mathrm{H}-\delta$, Pro-2), 3.02 (s, 3H, $\left.\mathrm{NCH}_{3}\right), 2.68\left(\mathrm{~s}, 3 \mathrm{H}, \mathrm{NCH}_{3}\right), 2.41(\mathrm{q}, J=5.5 \mathrm{~Hz}, 2 \mathrm{H}, \mathrm{H}-\beta$, Pro-2), $2.33(\mathrm{q}, J=5.65 \mathrm{~Hz}, 2 \mathrm{H}, \mathrm{H}-\beta$, Pro-1), $2.14(\mathrm{~d}, J=4.7 \mathrm{~Hz}, 2 \mathrm{H}, \mathrm{H}-\beta$, Phe), $1.88-1.62(\mathrm{~m}, 4 \mathrm{H}, \mathrm{H}-\gamma$, Pro-2 and Pro-1), $1.39(\mathrm{t}, J=6.25 \mathrm{~Hz}, 2 \mathrm{H}$, $\mathrm{H}-\beta$, Leu $), 0.97(\mathrm{~d}, J=6.3 \mathrm{~Hz}, 6 \mathrm{H}, \mathrm{H}-\delta$, Leu $), 0.77-0.62(\mathrm{~m}, 1 \mathrm{H}, \mathrm{H}-\gamma, \mathrm{Leu}) ;{ }^{13} \mathrm{C} \mathrm{NMR}\left(\mathrm{CDCl}_{3}\right): \delta=173.5$, 171.2 (2C, C=O, Leu and Pro-2), 170.4, 168.8 (2C, C=O, Phe and Pro-1), 137.2 (C- $\gamma$, Phe), 130.6 (2C, C- $m$, Phe), 127.9 (2C, C-o, Phe), 126.5 (C- $p$, Phe), 58.8 (C- $\alpha$, Phe), 55.5 (C- $\alpha$, Pro-2), 54.2 (C- $\alpha$, Pro-1), 51.8 (C- $\alpha$, Leu $), 48.3,47.1$ (2C, C- $\delta$, Pro-1 and Pro-2), $39.2(\mathrm{C}-\beta, \mathrm{Phe}), 37.4\left(\mathrm{NCH}_{3}\right), 35.7\left(\mathrm{NCH}_{3}\right), 34.1,32.4(2 \mathrm{C}$, C- $\beta$, Leu and Pro-1), 31.5 (C- $\beta$, Pro-2), 28.5 (C- $\gamma$, Leu), 24.6 (2C, C- $\delta$, Leu), 22.9 (C- $\gamma$, Pro-1), 21.8 (C- $\gamma$, Pro-2); FABMS: $m / z=483\left[(\mathrm{M}+\mathrm{H})^{+}, 100\right], 455\left[(483-\mathrm{CO})^{+}, 15\right], 386$ [(HN(Me)Leu-Pro-N(Me)Phe $)^{+}$,

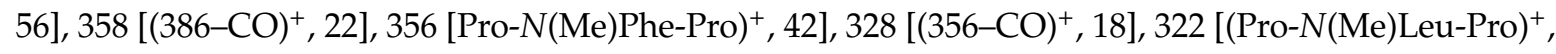
39], $294\left[(322-\mathrm{CO})^{+}, 19\right], 259$ [(HN(Me)Phe-Pro $\left.)^{+}, 66\right], 231\left[(259-\mathrm{CO})^{+}, 19\right], 225\left[(\mathrm{HN}(\mathrm{Me}) \text { Leu-Pro })^{+}\right.$, 47], $197\left[(225-\mathrm{CO})^{+}, 27\right], 162\left[(\mathrm{HN}(\mathrm{Me}) \mathrm{Phe})^{+}, 29\right], 134$ [N(Me)Phe immonium ion $\left.\left(\mathrm{C}_{9} \mathrm{H}_{12} \mathrm{~N}\right)^{+}, 16\right], 128$ $\left[(\mathrm{HN}(\mathrm{Me}) \mathrm{Leu})^{+}, 32\right], 100\left[\mathrm{~N}(\mathrm{Me})\right.$ Leu immonium ion $\left.\left(\mathrm{C}_{6} \mathrm{H}_{14} \mathrm{~N}\right)^{+}, 14\right], 98\left[(\mathrm{Pro})^{+}, 28\right], 91\left[\left(\mathrm{C}_{7} \mathrm{H}_{7}\right)^{+}, 9\right], 77$ $\left[\left(\mathrm{C}_{6} \mathrm{H}_{5}\right)^{+}, 10\right], 70$ [Pro immonium ion $\left.\left(\mathrm{C}_{4} \mathrm{H}_{8} \mathrm{~N}\right)^{+}, 21\right] ; 57\left[\left(\mathrm{C}_{4} \mathrm{H}_{9}\right)^{+}, 8\right], 43\left[\left(\mathrm{C}_{3} \mathrm{H}_{7}\right)^{+}, 11\right], 15\left[\left(\mathrm{CH}_{3}\right)^{+}, 19\right]$; $\mathrm{C}_{27} \mathrm{H}_{38} \mathrm{~N}_{4} \mathrm{O}_{4}$ (482): calcd. C 67.20, H 7.94, N 11.61; found C 67.19, H 7.95, N 11.63.

\subsection{Pharmacological Studies}

\subsubsection{Anthelmintic Screening}

The anthelmintic activity studies for the newly synthesized linear and cyclic $N$-methylated tetrapeptides $(3,4)$ were carried out against the three different species of the earthworms $M$. konkanensis, P. corethruses, and E. eugeniae at a concentration of $2 \mathrm{mg} / \mathrm{mL}$. Suspensions of the samples were prepared by triturating the synthesized compounds $(100 \mathrm{mg})$ with Tween $80(0.5 \%)$ and distilled water and the resulting mixtures were stirred using a mechanical stirrer for $30 \mathrm{~min}$. The suspensions were 
diluted to contain $0.2 \% w / v$ of the test samples. Suspensions of the reference drug, Mebendazole, were prepared with the same concentration in a similar way. Five earthworms per earthworm species under investigation were evaluated in triplicate. Earthworms of similar size (2 inches in length) were placed in Petri plates having a 4-inch diameter, containing $50 \mathrm{~mL}$ of the suspension of the test sample and the reference drug at room temperature (RT). Another set of five earthworms was maintained as a control in $50 \mathrm{~mL}$ of suspension of the distilled water and Tween $80(0.5 \%)$. The paralysis and death times were noted and their mean was calculated for the triplicate sets. The death time was ascertained by placing the earthworms in warm water $\left(50^{\circ} \mathrm{C}\right)$, which stimulated movement if the worm was alive. The results of the anthelmintic studies are compiled in Table 1.

\subsubsection{Antibacterial Screening}

The newly synthesized linear and cyclic $N$-methylated proline-rich tetrapeptides $(3,4)$ were evaluated for their antibacterial potential against two Gram-positive bacteria (B. subtilis and S. aureus) and two Gram-negative bacteria (P. aeruginosa and K. pneumoniae) at concentrations ranging from $6.25-50 \mu \mathrm{g} / \mathrm{mL}$. The minimum inhibitory concentration (MIC) values of test compounds were determined by the Tube Dilution Technique. Both the linear and cyclic tetrapeptides were dissolved separately to prepare a stock solution of $1 \mathrm{mg} / \mathrm{mL}$ using dimethylformamide (DMF). The stock solution was aseptically transferred and suitably diluted with the sterile broth medium to contain seven different concentrations of each test compound, ranging from 3.1-200 $\mu \mathrm{g} / \mathrm{mL}$ in different test tubes. The tubes were inoculated with one loopful of overnight growth culture of the test bacteria. The process was repeated with the different test bacteria and the different samples. The tubes inoculated with bacterial cultures were incubated at $37^{\circ} \mathrm{C}$ for $18 \mathrm{~h}$ and the presence/absence of growth of the bacteria was observed. From these results, the MIC of each test compound was determined against each test bacterium. A possible spore suspension was prepared in sterile distilled water from 5-day-old culture of the test bacteria growing on nutrient broth media. About $20 \mathrm{~mL}$ of the growth medium was transferred into the sterilized Petri plates and inoculated with $1.5 \mathrm{~mL}$ of the spore suspension (spore concentration $\sim 6 \times 10^{4}$ spores $/ \mathrm{mL}$ ). Filter paper disks having a 6-mm diameter and a 1-mm thickness were sterilized by autoclaving at $121^{\circ} \mathrm{C}(15 \mathrm{psi})$ for $15 \mathrm{~min}$. Each Petri plate was divided into five equal portions along the diameter to place one disc. Three discs of the test sample were placed on three portions together with one disc with the reference drug (Gatifloxacin) and a disk impregnated with the solvent (DMF) as the negative control. The Petri plates inoculated with bacterial cultures were incubated at $37^{\circ} \mathrm{C}$ for $18 \mathrm{~h}$. Diameters of the zones of inhibition (ZOI in $\mathrm{mm}$ ) were measured and the average diameters of the test samples were calculated in triplicate. The diameters obtained for the test samples were compared with that produced by the standard drug. The results of the antibacterial studies are presented in Table 2.

\subsubsection{Antifungal Screening}

The serial plate dilution method was used for the evaluation of antifungal activity against the diamorphic fungal strain C. albicans and three other fungal strains, including A. niger and two cutaneous fungal strains, M. audouinii and T. mentagrophytes, at concentrations ranging from $6.25-50 \mu \mathrm{g} / \mathrm{mL}$ for the newly synthesized linear and cyclic tetrapeptides $(3,4)$. The MIC values of the test compounds were determined by employing the same technique as that used for the antibacterial studies using dimethyl sulfoxide (DMSO) instead of DMF, and the tubes inoculated with fungal cultures were incubated at $37^{\circ} \mathrm{C}$ for $48 \mathrm{~h}$. After incubation, the presence/absence of the fungal growth was observed and MIC of the test compounds was determined against each test fungus. A spore suspension in normal saline $(0.91 \% w / v$ of $\mathrm{NaCl})$ was prepared from the culture of the test fungi on Sabouraud's broth media. After transferring the growth medium, the Petri plates were inoculated with the spore suspension. After drying, wells were made using an agar punch and the test samples, reference drug (Griseofulvin), and negative control (DMSO) were placed in the labeled wells in each Petri plate. The Petri plates inoculated with the fungal cultures were incubated at $37^{\circ} \mathrm{C}$ for $48 \mathrm{~h}$. Antifungal activity 
was determined by measuring the diameter of the inhibition zone for the triplicate sets. The activity of each compound was compared with the reference standard. The results of the antifungal studies are given in Table 2.

The experimental details of the biological activity studies are described in our earlier reports [43-52]. Further, in order to describe the intermolecular forces of drug receptor interaction as well as the transport and distribution of drugs in a quantitative manner, various steric and the lipophilicity parameters need to be calculated for the synthesized linear and cyclic tetracyclopeptides $(3,4)$. As per International Union of Pure and Applied Chemistry (IUPAC) rules, tetracyclopeptide 4 can be named as 6-Benzyl-14-isobutyl-7,15-dimethylperhydrodipyrrolo[1,2-a:1,2-g] [1,4,7,10] tetraazacyclododecine-5,8,13,16-tetraone.

\section{Conclusions}

An efficient strategy was developed toward the first total synthesis of an $N$-methylated analog of tetracyclopeptide (4) utilizing carbodiimide chemistry. The EDC. $\mathrm{HCl} / \mathrm{NMM}$ coupling method provided $9-10 \%$ additional yield in comparison to the methods utilizing EDC.HCl/TEA and DCC/TEA or NMM. The $p$-nitrophenyl ester was shown to be better for the activation of the acid functionality of the linear tetrapeptide unit in comparison to pentafluorophenyl ester. The NMM was found to be a better base for the intramolecular cyclization of the linear peptide segment in comparison to pyridine. Like other proline-containing synthetic cyclooligopeptides, the synthesized $N$-methylated tetracyclopeptide displayed potent anthelmintic activity against $M$. konkanensis, P. corethruses, and E. eugeniae as well as effectiveness against pathogenic M. audouinii, T. mentagrophytes, and C. albicans. Further, Gram-negative bacteria were found to be more sensitive than Gram-positive bacteria towards the newly synthesized tetracyclopeptide at the concentrations tested. The improved pharmacological activity results of the $N$-methylated analog further proved the potential of $\mathrm{N}$-methylation in modulating biological activity and selectivity. On passing toxicity tests, tetracyclopeptide 4 may prove to be a good candidate for clinical studies and perhaps eventual consideration as a new anthelmintic and antifungal drug.

Supplementary Materials: The following are available online at http://www.mdpi.com/1660-3397/16/ 9/305/s1, Figures S1-S3: ${ }^{1} \mathrm{H}$ NMR, ${ }^{13} \mathrm{C}$ NMR and mass spectrum for newly synthesized $N$-methylated proline-rich tetracyclopeptide, Table S1: Various steric and the lipophilicity parameters for the linear and cyclic tetracyclopeptides.

Author Contributions: All authors were involved uniformly in all aspects of the work conducted for this paper.

Acknowledgments: The authors are thankful to the Faculty of Pharmacy, Jamia Hamdard University, Jamia Hamdard, Delhi, India for spectral analysis. Also, sincere thanks to the C.P.C.R.I., Kasaragod, Kerala, India for providing the earthworms for the testing of anthelmintic activity.

Conflicts of Interest: The authors declare no conflict of interest.

\section{References}

1. König, G.M.; Kehraus, S.; Seibert, S.F.; Abdel-Lateff, A.; Müller, D. Natural products from marine organisms and their associated microbes. ChemBioChem 2006, 7, 229-238. [CrossRef] [PubMed]

2. Urda, C.; Fernández, R.; Rodríguez, J.; Pérez, M.; Jiménez, C.; Cuevas, C. Daedophamide, a cytotoxic cyclodepsipeptide from a Daedalopelta sp. sponge collected in Indonesia. J. Nat. Prod. 2017, 80, 3054-3059. [CrossRef] [PubMed]

3. Pathak, D.; Dahiya, R. Cyclic peptides as novel antineoplastic agents: A review. J. Sci. Pharm. 2003, 4, 125-131.

4. Fang, W.Y.; Dahiya, R.; Qin, H.L.; Mourya, R.; Maharaj, S. Natural proline-rich cyclopolypeptides from marine organisms: Chemistry, synthetic methodologies and biological status. Mar. Drugs 2016, 14, 194. [CrossRef] [PubMed]

5. Langenfeld, A.; Blond, A.; Gueye, S.; Herson, P.; Nay, B.; Dupont, J; Prado, S. Insecticidal cyclodepsipeptides from Beauveria felina. J. Nat. Prod. 2011, 74, 825-830. [CrossRef] [PubMed] 
6. Dahiya, R. Cyclopolypeptides with antifungal interest. Coll. Pharm. Commun. 2013, 1, 1-15.

7. Dahiya, R.; Pathak, D. Cyclic peptides: New hope for antifungal therapy. Egypt. Pharm. J. (NRC) 2006, 5, 189-199.

8. Daletos, G.; Kalscheuer, R.; Koliwer-Brandl, H.; Hartmann, R.; de Voogd, N.J.; Wray, V.; Lin, W.; Proksch, P. Callyaerins from the marine sponge Callyspongia aerizusa: Cyclic peptides with antitubercular activity. J. Nat. Prod. 2015, 78, 1910-1925. [CrossRef] [PubMed]

9. Randazzo, A.; Bifulco, G.; Giannini, C.; Bucci, M.; Debitus, C.; Cirino, G.; Gomez-Paloma, L. Halipeptins A and B: Two novel potent anti-inflammatory cyclic depsipeptides from the Vanuatu marine sponge Haliclona species. J. Am. Chem. Soc. 2001, 123, 10870-10876. [CrossRef] [PubMed]

10. Lu, Z.; Van Wagoner, R.M.; Harper, M.K.; Baker, H.L.; Hooper, J.N.; Bewley, C.A.; Ireland, C.M.; Mirabamides, E.H. HIV-inhibitory depsipeptides from the sponge Stelletta clavosa. J. Nat. Prod. 2011, 74, 185-193. [CrossRef] [PubMed]

11. Fukuhara, K.; Takada, K.; Okada, S.; Matsunaga, S. Nazumazoles D-F, cyclic pentapeptides that inhibit chymotrypsin, from the marine sponge Theonella swinhoei. J. Nat. Prod. 2016, 79, 1694-1697. [CrossRef] [PubMed]

12. Tripathi, A.; Puddick, J.; Prinsep, M.R.; Rottmann, M.; Tan, L.T. Lagunamides A and B: Cytotoxic and antimalarial cyclodepsipeptides from the marine cyanobacterium Lyngbya majuscula. J. Nat. Prod. 2010, 73, 1810-1814. [CrossRef] [PubMed]

13. Pan, Z.; Wu, C.; Wang, W.; Cheng, Z.; Yao, G.; Liu, K.; Li, H.; Fang, L.; Su, W. Total synthesis and stereochemical assignment of gymnopeptides A. and B. Org. Lett. 2017, 19, 4420-4423. [CrossRef] [PubMed]

14. Kumar, S.; Dahiya, R.; Khokra, S.L.; Mourya, R.; Chennupati, S.V.; Maharaj, S. Total synthesis and pharmacological investigation of cordyheptapeptide A. Molecules 2017, 22, E682. [CrossRef] [PubMed]

15. Chatterjee, J.; Rechenmacher, F.; Kessler, H. N-methylation of peptides and proteins: An important element for modulating biological functions. Angew. Chem. Int. Ed. Engl. 2013, 52, 254-269. [CrossRef] [PubMed]

16. Prashad, M.; Har, D.; Hu, B.; Kim, H.-Y.; Repic, O.; Blacklock, T.J. An efficient and practical N-methylation of amino acid derivatives. Org. Lett. 2003, 5, 125-128. [CrossRef] [PubMed]

17. Di Gioia, M.L.; Leggio, A.; Liguori, A.; Perri, F. Solid-phase synthesis of N-nosyl- and $N$-Fmoc-N-Methyl- $\alpha$-amino acids. J. Org. Chem. 2007, 72, 3723-3728. [CrossRef] [PubMed]

18. Aurelio, L.; Brownlee, R.T.C.; Hughes, A.B. Synthetic preparation of $N$-methyl- $\alpha$-amino acids. Chem. Rev. 2004, 104, 5823-5846. [CrossRef] [PubMed]

19. Chatterjee, J.; Gilon, C.; Hoffman, A.; Kessler, H. N-methylation of peptides: A new perspective in medicinal chemistry. Acc. Chem. Res. 2008, 41, 1331-1342. [CrossRef] [PubMed]

20. Rader, A.F.B.; Reichart, F.; Weinmuller, M.; Kessler, H. Improving oral bioavailability of cyclic peptides by N-methylation. Bioorg. Med. Chem. 2018, 26, 2766-2773. [CrossRef] [PubMed]

21. Asfaw, H.; Laqua, K.; Walkowska, A.M.; Cunningham, F.; Martinez-Martinez, M.S.; Cuevas-Zurita, J.C.; Ballell-Pages, L.; Imming, P. Design, synthesis and structure-activity relationship study of Wollamide B; a new potential anti TB agent. PLoS ONE 2017, 12, e0176088. [CrossRef] [PubMed]

22. Dahiya, R.; Maheshwari, M.; Kumar, A. Toward the synthesis and biological evaluation of hirsutide. Monatsh. Chem. 2009, 140, 121-127. [CrossRef]

23. Dahiya, R.; Pathak, D. First total synthesis and biological evaluation of halolitoralin A. J. Serb. Chem. Soc. 2007, 72, 101-107. [CrossRef]

24. Dahiya, R.; Gautam, H. Solution phase synthesis and bioevaluation of cordyheptapeptide B. Bull. Pharm. Res. 2011, 1, 1-10.

25. Dahiya, R.; Pathak, D. Synthesis, characterization and biological evaluation of halolitoralin BA natural cyclic peptide. Asian J. Chem. 2007, 19, 1499-1505.

26. Rungprom, W.; Siwu, E.R.O.; Lambert, L.K.; Dechsakulwatana, C.; Barden, M.C.; Kokpol, U.; Blanchfield, J.T.; Siwu, E.R.O.; Kita, M.; Garson, M.J. Cyclic tetrapeptides from marine bacteria associated with the seaweed Diginea sp. and the sponge Halisarca ectofibrosa. Tetrahedron 2008, 64, 3147-3152. [CrossRef]

27. Dahiya, R.; Gautam, H. Synthesis and pharmacological studies on a cyclooligopeptide from marine bacteria. Chin. J. Chem. 2011, 29, 1911-1916.

28. Bodanszky, M.; Bodanszky, A. The Practice of Peptide Synthesis; Springer: New York, NY, USA, 1984; pp. 78-143.

29. Dahiya, R.; Pathak, D.; Himaja, M.; Bhatt, S. First total synthesis and biological screening of hymenamide E. Acta Pharm. 2006, 56, 399-415. [PubMed] 
30. Das, P.; Himaja, M. Design and synthesis of 4-[2'-(5'-nitro) imidazolyl] benzoyl ( $N$-methyl) amino acids and peptides. Int. J. Drug Dev. Res. 2010, 2, 364-370.

31. Garg, L.C.; Atal, C.K. Anthelmintic activity of Myrsine africana. Indian J. Pharm. Sci. 1963, 59, $240-245$.

32. Bauer, A.W.; Kirby, W.M.; Sherris, J.C.; Turck, M. Antibiotic susceptibility testing by a standardized single disk method. Am. J. Clin. Path. 1996, 45, 493-496. [CrossRef]

33. Dahiya, R.; Singh, S.; Kaur, K.; Kaur, R. Total synthesis of a natural cyclooligopeptide from fruits of sugar-apples. Bull. Pharm. Res. 2017, 7, 151.

34. Gagnon, M.G.; Roy, R.N.; Lomakin, I.B.; Florin, T.; Mankin, A.S.; Steitz, T.A. Structures of proline-rich peptides bound to the ribosome reveal a common mechanism of protein synthesis inhibition. Nucl. Acids Res. 2016, 44, 1-12. [CrossRef] [PubMed]

35. Matejuk, A.; Leng, Q.; Begum, M.D.; Woodle, M.C.; Scaria, P.; Chou, S.T.; Mixson, A.J. Peptide-based antifungal therapies against emerging infections. Drugs Future 2010, 35, 197. [CrossRef] [PubMed]

36. Kaneria, M.J.; Rakholia, K.D.; Chanda, S.V. Role of medicinal plants and bioactive compounds against skin disease-causing microbes, with special emphasis on their mechanisms of action. In The Microbiology of Skin, Soft Tissue, Bone and Joint Infections; Kon, K., Rai, M., Eds.; Academic Press: Cambridge, MA, USA, 2017; Volume 2, pp. 255-269.

37. Boddy, L. Interactions with humans and other animals. In The Fungi, 3rd ed.; Watkinson, S.C., Boddy, L., Money, N.P., Eds.; Academic Press: Cambridge, MA, USA, 2015; pp. 293-336.

38. Weedon, D. Mycoses and algal infections. In Weedon's Skin Pathology, 3rd ed.; Weedon, D., Ed.; Churchill Livingstone: London, UK, 2010; pp. 581-602.

39. Wu, M.; Li, X. Klebsiella pneumoniae and Pseudomonas aeruginosa. In Molecular Medical Microbiology, 2nd ed.; Tang, Y.W., Sussman, M., Liu, D., Poxton, I., Schwartzman, J., Eds.; Academic Press: Cambridge, MA, USA, 2015; Volume 3, pp. 1547-1564.

40. Bodey, G.P.; Bolivar, R.; Fainstein, V.; Jadeja, L. Infections caused by Pseudomonas aeruginosa. Rev. Infect. Dis. 1983, 5, 279-313. [CrossRef] [PubMed]

41. Kaletta, T.; Hengartner, M.O. Finding function in novel targets: C. elegans as a model organism. Nat. Rev. Drug Discov. 2006, 5, 387-399. [CrossRef] [PubMed]

42. Barnett, R.E.; Bailey, D.C.; Hatfield, H.E.; Fitsanakis, V.A. Caenorhabditis elegans: A model organism for nutraceutical safety and toxicity evaluation. In Neutraceuticals: Efficacy, Safety, and Toxicity; Gupta, R.C., Ed.; Academic Press: Cambridge, MA, USA, 2016; pp. 341-354.

43. Dahiya, R.; Mourya, R. Synthesis and antimicrobial screening of some novel halogenated phenoxyacetyl amino acid and peptide analogs. Bull. Pharm. Res. 2012, 2, 56-65.

44. Dahiya, R.; Pathak, D. Synthetic studies on novel benzimidazolopeptides with antimicrobial, cytotoxic and anthelmintic potential. Eur. J. Med. Chem. 2007, 42, 772-798. [CrossRef] [PubMed]

45. Dahiya, R.; Singh, S.; Sharma, A.; Chennupati, S.V.; Maharaj, S. First total synthesis and biological screening of a proline-rich cyclopeptide from a Caribbean marine sponge. Mar. Drugs 2016, 14, 228. [CrossRef] [PubMed]

46. Dahiya, R.; Gautam, H. Toward the synthesis and biological screening of a cyclotetrapeptide from marine bacteria. Mar. Drugs 2011, 9, 71-81. [CrossRef] [PubMed]

47. Dahiya, R.; Gautam, H. Total synthesis and antimicrobial activity of a natural cycloheptapeptide of marine-origin. Mar. Drugs 2010, 8, 2384-2394. [CrossRef] [PubMed]

48. Dahiya, R.; Singh, S. Synthesis, characterization and biological screening of diandrine A. Acta Pol. Pharm. 2017, 74, 873-880. [PubMed]

49. Dahiya, R.; Singh, S. Toward the Synthesis and pharmacological screening of a natural cycloheptapeptide of plant origin. Nat. Prod. Commun. 2017, 12, 379-383.

50. Dahiya, R.; Singh, S. Synthesis, characterization, and biological activity studies on fanlizhicyclopeptide A. Iran. J. Pharm. Res. 2017, 16, 1178-1186. 
51. Dahiya, R. Synthesis, spectroscopic and biological investigation of cyclic octapeptide: Cherimolacyclopeptide G. Turk. J. Chem. 2008, 32, 205-215.

52. Dahiya, R.; Kumar, A.; Yadav, R. Synthesis and biological activity of peptide derivatives of iodoquinazolinones/nitroimidazoles. Molecules 2008, 13, 958-976. [CrossRef] [PubMed]

(c) 2018 by the authors. Licensee MDPI, Basel, Switzerland. This article is an open access article distributed under the terms and conditions of the Creative Commons Attribution (CC BY) license (http:/ / creativecommons.org/licenses/by/4.0/). 